\title{
HOME-THOUGHTS, FROM ABROAD
}

Marija Krivokapić, University of Montenegro, marija13a@gmail.com

Aleksandra Nikčević Batrićević, University of Montenegro,

alexmontenegro@t-com.me

DOI: $10.31902 /$ fll.31.2020.1

UDK: 821.111(73).09

The papers collected in this issue are the result of the XV International Conference on Anglo-American Literary Studies that took place in Cetinje, Montenegro, on June 27-28, 2019, at the National Library "Đurđe Crnojević" and the American Corner.

The conference topic is taken from Robert Browning's poem of the same title. In this poem, the lyrical persona imagines what England, his/her home country, looks like in spring. Browning wrote the poem from his self-exile in Italy, when he, as many of his compatriots, early modernists and modernists, believed it to be morally imperative to interrogate the concept and the values of home, answering thus Heidegger's concurrent fear that modernity is incapable of dwelling mostly due to alienation and technology. However, the momentousness of the topic comes through the global image of massive population shifts, on one, and the deterritorialization of home through digital media, on the other hand. Furthermore, as home is not only a particular physical space, but also a place in memory and a representational space, it has often been searched through cultural formations and rituals, individual names and bodies, and, thus, could be also found and founded in literature. Apart from this, the plurality of the title was to invite the participants to explore various approaches and interpretations of this topic (not only literary but also cultural, social, historical...), moving from the very broad concept to those more particular and circumscribed.

The cluster opens with the paper "Home Thoughts, from Abroad: The Fantasy of 'Blighty,' the Reality of Home" by Michael Hollington, life member of the Clare Hall at Cambridge University. One certainly longs for home most when one is forcefully denied it, such as in cases of wars or political immigrations. Hollington shows how World War l's soldiers longing for home interestingly expressed itself through a variation of the use of the word "blighty." Hollington explains that the word has Anglo-Indian origin in the word "bilayati," derived from Arabic "wilayati," that, actually, referred to an unfamiliar or foreign 
territory, and eventually Europe. In the substandard speech of the British soldiers of the period this word soon got phonetically, and often humorously, associated with the word "blighty," which originally meant a minor wound, but still a wound that would determine soldier's transmission back home for treatment. Through a number of examples from popular songs to anti-war poetry and prose, Hollington shows how the word gradually, by connoting a means through which one can get home, took the meaning of "home," or "Blighty Great Britain," as it says in Robert Graves's poem "Goodbye to All That" that Hollington quotes. However, Hollington shows, "Blighty" soon stopped being associated with a paradise the soldiers longed for and became a place of unrest, frustration, and fears for the young people exposed to constant aggressive attacks who could never come back home the same. It became a place that could not comprehend the various wounds the war inflicted on the soldiers, as is probably most sharply depicted, as Hollington notes, in Sassoon's poem "Blighters."

In her paper "Memories and Stories of Returning Home in Khaled Hosseini's Novels The Kite Runner, And the Mountains Echoed, A Thousand Splendid Suns," Elena Spirovska, from South East European University in Northern Macedonia, explains that thinking of home becomes substantial for an American writer of Afghan origin, who left his home country as a child, moved to the US, and has ever accepted the new home in an ambiguous way. Returning home in Hosseini's novels becomes, as Spirovska derives, either an act of redemption, of paying respect to the past life of the loved ones, a means of exploring one's personality, or rather a metaphorical travel in the form of homesickness. However, every time this is an involuntary act driven by a variety of motives, an act that provides some answers but not a life fulfilment. This prevailing interest makes Hosseini a diasporic writer in the most direct sense.

In "Inhabiting the British Country House in India: The Inheritance of Loss by Kiran Desai," Natacha Lasorak, from École Normale Supérieure de Lyon, examines one of Desai's most commended novels that has been largely read through the tools of diaspora studies. However, within a reversed perspective it becomes interesting to Lasorak to look at how, years after British dominance ceased, some Indians still try to mimic a British way of life, i.e. behave as surrogate Britons in their home country, now independent India, by living in a Nineteenth-century English manor. This aspect is analyzed, among other relevant insights, with the background of Homi Bhabha's elaboration of the concept of mimicry developed in The Location of Culture. As the house stands for the stability of English values, Lasorak, 
therefore, examines the Englishness its occupants represent, or perform. The irony that pervades the novel comes from the main characters' reenacting a mythic version of their adoptive England. By underlying the prevalence of the colonial state of mind, the novel also parodies the genre of the English manor house novel typical of the colonial period, such as Jane Austen's Mansfield Park, which Lasorak discusses in detail. However, as the characters' sense of home remains unsustainable, the house gradually crumbles, concurrent to the vital social and political disturbances that surround it.

"Writing in Absentia: Nostalgia and Anti-Nostalgia in the Essays of Georgi Markov" is a paper by Tom Phillips from University of Sofia "St Kliment Ohridski." Phillips is interested in the radio reports Bulgarian author, scriptwriter and journalist Georgi Markov wrote from Britain between 1975 and his assassination in 1978. The title of the original Bulgarian collection of the essays Задочни репортажи за задочна България Phillips translates as Reports in absentia on an absent Bulgaria. These reports, or essays, are about Bulgaria Markov knew in the 1950s and 1960s. Although they show, as Phillips argues, a "world of bleak absurdities, cruel injustices, cults of personality, hypocrisy, and endless frustrations," Phillips does not consider them only as a dissident polemic, but also as pieces of literature in exile, because as much as they do criticize the communist system in Bulgaria, they are also molded by the author's obvious nostalgia for an absent country which Markov believed might be recovered and possible. However, the Bulgaria Marko yearns for is not simply a pre-communist Bulgaria or a mythic country with its traditional values, beliefs, rituals, and behaviours.

John C. Spurlock, from Seton Hill University, Greensburg, PA, USA, contributes to the collection with the paper titled "Furnaces: Visions of the American Dream and Nightmare in Braddock." The paper discusses a novel Out of this Furnace by Thomas Bell and a movie, which appeared more than 70 years after the novel, Out of the Furnace directed by Scott Cooper, These two works show, as Spurlock argues, "the arc" between the development and establishment of the American dream, in the early 20th-century mill towns near Pittsburgh, and the final crush of the dream in the setting of deindustrialized town of Braddock, Pennsylvania. These works share the title, the steel-mill setting, and the characters taken from the working class that allow to consider them as, Spurlock says, "a fictional biography of an American industry and of the American working class." The novel follows three generations of Slovak immigrants who attempt to assimilate and live the American dream, and who progress from manual workers to to 
union leaders, feeling fully American. Instead of portraying three generations, the movie is focused on the period of five years only, from 2008 to 2012, to depict the results of the dissolved American dream in the forms of job loss, debt, violence, drug and alcohol abuse, and PTSD brought from the wars the US fought outside its borders. While in the novel the town shows progress, it is not depicted as an idyllic place. Its atmosphere is grey, filled with factories' smoke, polluted river, poverty ghettoes populated by waves of immigrants who try to make it a livable domesticated space. In the movie, the population of the town is decimated, the streets are empty, the houses are abandoned and ravished, with only gambling places resembling some form of life.

The paper that closes the cluster is "Right then, left now: Constructing 'Macedonia' in the Macedonian diasporas in Australia and Europe," by Aleksandar Takovski from the AAB College in Priština, Kosovo, and Maja Muhić, from the South East European University, in Tetovo and Skopje, North Macedonia. The paper discusses two immigration waves of Macedonians, the first one to Australia and the US, and the second, that took place after the 1991, mostly to Europe. While both diasporas where determined by a search for a more comfortable life, the latter also had its political reasons. Therefore, the authors presume that these two communities must have constructed their own different images of "Macedonia" and venture into the study of their highly identity mobilizing discourses on their home land, mostly collected from the FB sites of different Macedonian immigrant online communities in Australia and Europe. These sources show five specific tendencies, which the authors identify as attempts to show homeland as a historical narrative, homeland as a political differentiation/ boundary making, homeland as practice of national identity, banal nationalism, and the "we feeling" of pride and empathy for the fellow compatriot.

The papers present in this cluster discuss home through the analysis of works of literature of different genres and other cultural formations as an amoebic and often controversial concept made such due to numerous abrupt social, political, and technological shifts that humanity witnessed in, at least, the last century. The hypermobility of the present era, which develops both physically, geographically, and digitally, seems to be only further blurring the sense of home - the place of security, stability, intimacy, and identity - we once knew. We hope we have contributed to the growing discussion of the matter and that this cluster will find readers not only in the field of AngloAmerican studies, but also in the humanities in general. 